\section{Pediatric thyroid carcinoma: experience in pediatric hospital}

\author{
João Henrique Cunha Villela1*, Luiz Roberto Medina dos Santos², \\ Camila Medeiros Machado', Fernanda Cecconello', Vinicius Muraro Bonatto ${ }^{1}$
}

\begin{abstract}
Introduction: Thyroid malignancies are not common in the pediatric patients. The objective of this study was to analyze the thyroid cancer patients operated on in a Pediatric Hospital, between 2012 and 2016, with a description of the diagnosis and therapeutics, including a review of the literature. Methods: A retrospective study by reviewing medical records in a Pediatric Hospital, from 1/1/2012 to 12/31/2016. Results: Ten patients diagnosed with thyroid cancer were analyzed in the five years' period. The female gender was the most affected with $60 \%$ of the cases and $70 \%$ of the patients undergone total thyroidectomy associated with some kind of neck dissection. The main histological type was papillary carcinoma in $80 \%$ of the cases. All patients are alive and well, in a careful follow-up. Conclusion: The results were in accordance to the epidemiological and clinical features observed in the literature, for this pediatric population. It is important a long follow up for these patients.
\end{abstract}

Keywords: thyroid neoplasms; carcinoma, papillary; pediatrics; thyroid nodule.

\section{Introduction}

Thyroid neoplasms are not common in the pediatric age group ${ }^{1}$. In most children, the thyroid nodule is the initial presentation of thyroid cancer ${ }^{1,2}$. However, the presence of palpable lymph nodes in the cervical region may be the only indication in this age group ${ }^{3}$. Pediatric thyroid cancer tends to be more aggressive and multifocal, with greater involvement of the cervical lymph nodes and with a greater extracapsular extension of the disease, when compared to the same disease in adults ${ }^{4}$. Ten percent of all thyroid cancers occur in patients younger than 21 years old ${ }^{5}$. In Brazil, the incidence can reach $2 \%$ of all pediatric cancers, according to the National Cancer Institute database ${ }^{6}$, and differentiated thyroid carcinoma accounts for about $0.5-3 \%$ of all neoplasms in the pediatric population ${ }^{7}$. Also, the thyroid is one of the most common sites of a second primary tumor in children who have received radiation therapy in the neck for the treatment of other neoplasms.

Ultrasonography (US) is the best imaging test for the evaluation of the thyroid nodule, and it may suggest, but not diagnose, the etiology of the nodule ${ }^{8}$. Fine needle aspiration (FNA) is a diagnostic method with a good cost-benefit ratio and it is currently indicated as the first diagnostic option in patients with thyroid and cervical nodules ${ }^{9,10}$, as well as excellent sensitivity and specificity ${ }^{9,10}$.

Controversies over the aggressiveness of the clinical presentation and the optimal therapeutic approach remain in the scientific community. Current 
recommendations and test systems are based on data generated by studies in adults, which can lead to excessive or incomplete treatments. As in the adults, differentiated thyroid carcinoma is the most common, especially papillary carcinoma. The current treatment recommendation is total thyroidectomy followed by radioiodine therapy, when indicated, based on good response and high disease-free survival rate for the pediatric age group. However, many authors question the aggressiveness of this treatment, given the long-term survival of these patients and the long-term complications of high doses of radioactive iodine. Understanding the differences in biology, clinical course and outcomes in this population is crucial for making therapeutic decisions ${ }^{11}$. Although children and adolescents with differentiated thyroid carcinoma have more advanced disease at diagnosis, their prognosis is better than in adults ${ }^{12}$.

In the pediatric age group, most tumors are derived from follicular cells, such as papillary and follicular carcinomas ${ }^{13}$, with parafollicular cell carcinoma being less frequent.

The occurrence of thyroid carcinoma in early childhood is very rare. In the literature, there are isolated cases of differentiated thyroid carcinoma in neonates and infants less than one-year-old ${ }^{14,15}$.

\section{Methods}

This is a retrospective study that includes all patients aged 0 to 15 years old diagnosed with thyroid cancer after operated by the Head and Neck Surgery Service of Children's Hospital from 01/01/2012 to 12/31/2016.

Patients were identified by searching for all thyroid surgeries performed in the period with conference results of anatomopathological reports of surgical specimens and included in the study those diagnosed with thyroid cancer. The medical records of these patients were separated and reviewed.

The variables analyzed were age, gender, symptomatology, exposure to previous irradiation, family history, surgical indication, FNA of thyroid nodules and cervical lymph nodes when indicated, type of surgery, histological type, pathological staging, adjuvant with radioiodine therapy, serum thyroglobulin dosage, anti-thyroglobulin antibody, calcitonin and CEA when indicated, and eventual relapse.

\section{Results}

Ten patients with a diagnosis of thyroid carcinoma treated in this period of 5 years were identified.

The female gender was the most affected by thyroid cancer (six in ten patients). Age at diagnosis ranged from 5 to 13 years old. The presence of thyroid mass and cervical nodules were the most frequent symptoms. There was no record of prior exposure to ionizing radiation for any of these patients.

Nine patients underwent FNA of the thyroid nodule, resulting from the Bethesda classification ${ }^{16}$, where one patient had category Bethesda IV, three had Bethesda V and five had Bethesda VI. Four patients underwent FNA of cervical lymph node, which demonstrated metastatic papillary carcinoma. 
In one patient, total prophylactic thyroidectomy was indicated by a familial multiple endocrine neoplasia type Ila (NEM Ila) and having RET +.

Two patients underwent total thyroidectomy, and eight patients underwent total thyroidectomy associated with neck dissection, three of which were to unilateral level VI, two to central compartment and three to central and lateral compartiments.

Eight patients had a diagnosis of papillary carcinoma, with three presenting multicentricity, six of them with positive cervical lymph node metastasis (four with prior diagnosis and two after transient suspicion in the perioperative period), a follicular carcinoma and a medullary microcarcinoma in a patient had the prophylactic surgical indication.

Radioiodine therapy was indicated for four patients, all with papillary carcinoma and positive cervical lymph node metastasis, with a dosage varying from 50 to $150 \mathrm{mCi}$, according to body weight and extent of disease evaluated through pathological staging. In one patient, only whole-body scintigraphy (WBS) was performed for control, without radioiodine therapy. In two patients with positive lymph node metastasis, but with encapsulated tumor, absence of extrathyroidal extension, perineural and angiolymphatic invasion, the choice was made without radioiodine therapy or WBS. Data are in Table 1.

All patients are undergoing rigorous follow-up, in hormonal replacement with levothyroxine, in suppressive doses for thyrotrophic hormone (TSH), and two patients are maintaining anti-thyroglobulin negative antibody and undetectable serum thyroglobulin. Five patients had anti-thyroglobulin-negative antibody and positive serum thyroglobulin level, but low and controlled (0.1 to $1.3 \mathrm{ng} / \mathrm{ml})$.

Table 1. Data from 10 patients diagnosed with thyroid cancer after surgery from 2012 to 2016.

\begin{tabular}{|c|c|c|c|c|c|c|}
\hline Gender & Indication/FNA & $\begin{array}{l}\text { Age in } \\
\text { Surgery }\end{array}$ & Surgery & AP & Current Staging & RIT \\
\hline $\mathrm{F}$ & NEM Ila Ret + & 5 years old & $\mathrm{TT}$ & $\begin{array}{l}\text { Medular } \\
\text { MicroCa }\end{array}$ & pT1aN0Mx & No \\
\hline M & IV & 13 years old & $\mathrm{TT}$ & Follicular CA & pT2NxMx & No \\
\hline $\mathrm{F}$ & VI & 9 years old & $\mathrm{TT}+$ Central ND & Papillary CA & pT3N1aMx & $50 \mathrm{mCi}$ \\
\hline M & V & 8 years old & $\begin{array}{c}\mathrm{TT}+\text { Central ND and } \\
\text { Lateral D }\end{array}$ & Papillary CA & pT1bN0Mx & No \\
\hline M & VI & 11 years old & TT + right level VI ND & Papillary CA & pT1aNOMx & No \\
\hline M & VI & 11 years old & $\begin{array}{l}\text { TT + Central ND and } \\
\text { Bilateral }\end{array}$ & Papillary CA & pT3N1bM1pul & $150 \mathrm{mCi}$ \\
\hline $\mathrm{F}$ & $\mathrm{V}$ & 9 years old & TT + Central ND & Papillary CA & pT2N1aMx & $50 \mathrm{mCi}$ \\
\hline $\mathrm{F}$ & $\mathrm{VI}$ & 13 years old & TT + right level VI ND & Papillary CA & pT2N1aMx & No \\
\hline $\mathrm{F}$ & V & 13 years old & TT + right level VI ND & Papillary CA & pT2N1aMx & $150 \mathrm{mCi}$ \\
\hline $\mathrm{F}$ & VI & 13 years old & $\begin{array}{c}\mathrm{TT}+\text { Central ND and } \\
\text { Lateral D }\end{array}$ & Papillary CA & pT1bN1bMx & No \\
\hline
\end{tabular}

$\mathrm{CEA}=$ Carcinoembryonic antigen, FNA = fine needle aspiration biopsy, AP $=$ Pathological report, ND = Neck dissection, Ca or CA = Carcinoma, NEM = Multiple endocrine neoplasms; RIT: radioiodine therapy; TT: total thyroidectomy. 
The patient with medullary microcarcinoma maintains stable calcitonin and CEA dosages $(2.0 \mathrm{pg} / \mathrm{ml}$ and $0.4 \mathrm{ng} / \mathrm{ml}$ respectively). In two patients, there was a high anti-thyroglobulin antibody (66.3 and $597 \mathrm{IU} / \mathrm{ml}$ ) and undetectable serum thyroglobulin, with no clinical evidence of relapse, and in a patient, there was anti-thyroglobulin antibody positive and low $(0.7 \mathrm{IU} / \mathrm{ml})$ and elevated serum thyroglobulin $(300 \mathrm{ng} / \mathrm{ml})$, with pulmonary metastases evidenced by WBS. (Table 2)

All patients are alive, well and in careful follow-up.

\section{Discussion}

Due to the fact that the thyroid volume is lower in children, early involvement of the thyroid capsule and the surrounding tissue can be observed, and multicentricity also occurs more frequently in this age group, especially in papillary carcinoma ${ }^{17,18}$. This is important because it favors the indication of total thyroidectomy as a primary surgical approach for these patients. Pediatric patients are more likely to have cervical lymphatic metastasis, as well as distant metastases ${ }^{19,20}$. In a Mayo Clinic series with 1039 patients with papillary thyroid carcinoma, involvement of cervical lymph nodes was detected in $90 \%$ and distant metastases in approximately $7 \%$ of children versus $35 \%$ of cervical lymph node involvement and $2 \%$ of distant metastasis in adults ${ }^{21}$. The most common site of distant metastasis in children is the lung, with only a few reported cases of bone metastases ${ }^{15}$ and metastases to the central nervous system ${ }^{15,22}$. The histological subtype follows a distribution similar to adults: $90-95 \%$ of papillary and 5\% of follicular carcinomas ${ }^{23-25}$. Undifferentiated tumors such as insular and anaplastic tumors are extremely rare ${ }^{25}$.

An important difference between pediatric and adult thyroid carcinomas is related to the high prevalence of expression of the sodium iodide transporter

Table 2. Data from the 10 patients followed up with the laboratory dosages collected between January and June 2017.

\begin{tabular}{cccc}
$\begin{array}{c}\text { Ac Anti-thyroglobulin } \\
(\text { Ul/ml) }\end{array}$ & $\begin{array}{c}\text { Thyroglobulin } \\
(\mathbf{n g} / \mathbf{m l})\end{array}$ & $\begin{array}{c}\text { Calcitonin } \\
(\mathbf{p g} / \mathbf{m l})\end{array}$ & $\begin{array}{c}\text { CEA } \\
\text { (ng/ml) }\end{array}$ \\
\hline Negative & 0.1 & 2 & 0.4 \\
\hline Negative & 0.3 & & \\
\hline Negative & Undetectable & \\
\hline Negative & 0.6 & \\
\hline 597 & Undetectable & \\
\hline 0.7 & 300 & \\
\hline 66.3 & 0.2 & \\
\hline Negative & 0.4 & \\
\hline Negative & 1.3 & \\
\hline Negative & Undetectable & \\
\hline
\end{tabular}

$\mathrm{CEA}=$ Carcinoembryonic antigen. 
(NIS) in the metastatic focus found in children ${ }^{26,27}$. The greater expression of NIS in the pediatric population results in a greater capacity to respond to treatment with radioactive iodine and a better prognosis. In young patients, the risk of recurrence increases in those who do not express the NIS protein when compared to those who have $i^{26}$. Thus, the degree of NIS expression correlates with the avidity of radioactive iodine for metastases ${ }^{28}$ and lower rates of clinical recurrence ${ }^{29}$.

The prognosis of these tumors in childhood is better and survival seems to be higher, despite having a higher rate of recurrence when compared to adults ${ }^{30}$.

Regardless of the biology of papillary and follicular tumors, the therapeutic approach is very similar for both tumor subtypes ${ }^{15,30}$. As in adults, the treatment of differentiated thyroid carcinoma is based on the combination of three therapeutic modalities: surgery, hormone replacement with levothyroxine and treatment with radioactive iodine. Surgery may range from lobectomy to total thyroidectomy accompanied by cervical, central and lateral neck dissection. The latest guidelines recommend total thyroidectomy, especially for tumors larger than $1 \mathrm{~cm}^{31-33}$, associated with neck dissection of the central or lateral compartment if lymph node metastases are observed at preoperative imaging or during surgery. The main surgical complications include persistent hypoparathyroidism and lower laryngeal nerve lesion, which can cause a wide spectrum of clinical consequences: from hoarseness to paralysis of both vocal folds, requiring definitive tracheostomy ${ }^{34}$.

The success of radioiodine ablation is significantly lower in patients undergoing less extensive surgery, such as near total thyroidectomy ${ }^{31,35}$. In most cases, a dose of radioiodine treatment is able to achieve complete ablation. However, the procedure may require repetition, usually 6-12 months after the first procedure ${ }^{36}$. Some variables seem to influence the success of thyroid remnant ablation, and the most important one seems to be the presence of lymph node metastases ${ }^{37}$.

Treatment with hormone replacement therapy with levothyroxine at a suppressive dose reduces the risk of TSH-induced growth or tumor proliferation $^{38}$. In children and adolescents still growing, there are several studies that guarantee the efficacy and safety of this replacement, particularly in relation to the final height, provided they are carefully controlled ${ }^{39}$.

Our study showed that the demand of patients with thyroid cancer was not large in the hospital during the period analyzed. Despite the low prevalence, the diagnosis of this neoplasm should be considered in the investigation of any child, adolescent or young adult with thyroid and cervical nodules, even if asymptomatic ${ }^{40}$.

Although children with thyroid cancer sometimes have locoregional metastases, a high rate of distant metastasis, and relapse, overall survival is very good ${ }^{4,12}$. Treatment should be based on increased risk of recurrence rather than overall mortality, and lifelong follow-up is necessary because recurrence and death may not occur for decades after diagnosis ${ }^{11}$.

There is still no ideal system for treating thyroid cancer in the pediatric population. These patients are usually grouped under 45 years old, causing 
imprecision when including those under 20 years old, who clearly have different clinical presentations and biology when compared to older patients ${ }^{11}$. More studies with this population are needed to develop specific behavior for this age group. All cases of pediatric thyroid cancer should be referred to specialized multidisciplinary teams to minimize possible complications and ensure adequate follow-up.

\section{Conclusion}

Uniform management was observed by physical examination of thyroid and/or cervical nodules, followed by evaluation of it through ultrasound and FNA, associated with trimodal treatment, with total thyroidectomy, neck dissection and radioiodine therapy when indicated, associated with suppressive therapy with levothyroxine and follow-up through physical examination, ultrasonography and laboratory control.

\section{References}

1. Cardoso AA, Pianovski MAD, França SN, Pereira RM, Boguzewski M, Sandrini R, Hakin Neto CA, Collaço LM, Graf H, Lacerda L Fo Câncer de tireoide na infância e adolescência - relato de 15 casos. Arq Bras Endocrinol Metabol. 2004;48(6):83541. http://dx.doi.org/10.1590/S0004-27302004000600009. PMid:15761557.

2. Spinelli C, Bertocchini A, Antonelli A, Miccoli P. Surgical therapy of the thyroid papillary carcinoma in children: experience with 56 patients 16 years old. J Pediatr Surg. 2004;39(10):1500-5. http://dx.doi.org/10.1016/j.jpedsurg.2004.06.016. PMid:15486894.

3. Monte O, Longui CA, Calliari LE, Kochi C, Scalissi NM, Uvo RA, Morone M. Thyroid carcinoma during childhood and adolescence. Endocrinologist. 2005;15(2):10610. http://dx.doi.org/10.1097/01.ten.0000157882.36440.1a.

4. Hegedüs L. Clinical practice. The thyroid nodule. N Engl J Med. 2004;351(17):176471. http://dx.doi.org/10.1056/NEJMcp031436. PMid:15496625.

5. Buckwalter JA, Gurll NJ, Thomas CG Jr. Cancer of the thyroid in youth. World J Surg. 1981;5(1):15-25. http://dx.doi.org/10.1007/BF01657826. PMid:7233950.

6. Instituto Nacional do Câncer - INCA. Childhood and adolescent cancer in brazil: data from mortality and population- based registries [Internet]. Rio de Janeiro: Instituto Nacional do Câncer; 2009 [cited august 10, 2017]. Available from: http:// www.inca.gov.br

7. Josefson J, Zimmerman D. Thyroid nodules and cancers in children. Pediatr Endocrinol Rev. 2008;6(1):14-23. PMid:18806721.

8. Tomimori EK, Camargo RY, Bisi H, Medeiros-Neto G. Combined ultrasonographic and cytological studies in the diagnosis of thyroid nodules. Biochimie. 1999;81(5):447-52. http://dx.doi.org/10.1016/S0300-9084(99)80094-7. PMid:10403174. 
9. Kessler A, Gavriel H, Zahav S, Vaiman M, Shlamkovitch N, Segal S, Eviatar E. Accuracy and consistency of fine-needle aspiration biopsy in the diagnosis and management of solitary thyroid nodules. Isr Med Assoc J. 2005;7(6):371-3. PMid:15984379.

10. Alves C, Silva MSD, Pinto LM, Toralles MBP, Freitas ICF. Aspectos clínicos e diagnósticos de nódulos tireoidianos em crianças e adolescentes. Rev Paul Pediatr. 2006;24:298-302.

11. Vaisman F, Corbo R, Vaisman M, Thyroid Carcinoma in Children and AdolescentsSystematic Review of the Literature. J Thyroid Res. 2011;2011:845362. http:// dx.doi.org/10.4061/2011/845362. PMID: 21904689.

12. Hung W, Sarlis NJ. Current controversies in the management of pediatric patients with well-differentiated nonmedullary thyroid cancer: a review. Thyroid. 2002;12(8):683-702. http://dx.doi.org/10.1089/105072502760258668. PMid:12225637.

13. Schlumberger MJ. Papillary and follicular thyroid carcinoma. N Engl J Med. 1998;338(5):297-306. http://dx.doi.org/10.1056/NEJM199801293380506. PMid:9445411.

14. Harness JK, Thompson NW, McLeod MK, Pasieka JL, Fukuuchi A. Differentiated thyroid carcinoma in children and adolescents. World J Surg. 1992;16(4):547-53, discussion 553-4. http://dx.doi.org/10.1007/BF02067317. PMid:1413825.

15. Newman KD, Black T, Heller G, Azizkhan RG, Holcomb GW 3rd, Sklar C, Vlamis V, Haase GM, La Quaglia MP. Differentiated thyroid cancer: determinants of disease progression in patients <21 years of age at diagnosis: a report from the surgical discipline committee of the children's cancer group. Ann Surg. 1998;227(4):53341. http://dx.doi.org/10.1097/00000658-199804000-00014. PMid:9563542.

16. Cibas ES, Ali SZ. The bethesda system for reporting thyroid cytopathology. Thyroid. 2009;19(11):1159. http://dx.doi.org/10.1089/thy.2009.0274. PMid:19888858.

17. Katoh R, Sasaki J, Kurihara H, Suzuki K, lida Y, Kawaoi A. Multiple thyroid involvement (intraglandular metastasis) in papillary thyroid carcinoma. A clinicopathologic study of 105 consecutive patients. Cancer. 1992;70(6):1585-90. http://dx.doi. org/10.1002/1097-0142(19920915)70:6<1585::AID-CNCR2820700623>3.0.CO;2-Z. PMid:1516009.

18. Pasieka JL, Thompson NW, McLeod MK, Burney RE, Macha M, Reeve TS. The incidence of bilateral well differentiated thyroid cancer found at completion thyroidec- tomy. World J Surg. 1992;16(4):711-6, discussion 716-7. http://dx.doi. org/10.1007/BF02067365. PMid:1413840.

19. Tuttle RM, Vaisman F, Tronko MD. Clinical presentation and clinical outcomes in Chernobyl-related paediatric thyroid cancers: what do we know now? What can we expect in the future? Clin Oncol. 2011;23(4):268-75. http://dx.doi.org/10.1016/j. clon.2011.01.178. PMid:21324656.

20. Robie DK, Dinauer CW, Michael Tuttle R, Ward DT, Parry R, McClellan D, Svec $\mathrm{R}$, Adair C, Francis $\mathrm{G}$. The impact of initial surgical management on outcome in young patients with differentiated thyroid cancer. J Pediatr Surg. 1998;33(7):113448, discussion 1139-40. http://dx.doi.org/10.1016/S0022-3468(98)90546-2. PMid:9694109. 
21. Zimmerman D, Hay ID, Gough IR, Goellner JR, Ryan JJ, Grant CS, McConahey WM. Papillary thyroid carcinoma in children and adults: long-term follow-up of 1039 patients conservatively treated at one institution during three decades. Surgery. 1988;104(6):1157-66. PMid:3194843.

22. Hay ID. Brain metastases from papillary thyroid carcinoma. Arch Intern Med. 1987;147(3):607-11, 611. http://dx.doi.org/10.1001/ archinte.1987.00370030205045. PMid:3827442.

23. Bernstein L, Gurney J. Carcinomas and other malignant epithelial neoplasms. In: National Cancer Institute. Cancer Incidence and Survival among Children and Adolescents: United States SEER Program 1975-1995. Bethesda: Cancer Statistics Branch, National Cancer Institute, 1999. p. 139-148.

24. Harach HR, Williams ED. Childhood thyroid cancer in England and Wales. Br J Cancer. 1995;72(3):777-83. http://dx.doi.org/10.1038/bjc.1995.410. PMid:7669594.

25. Hassoun AA, Hay ID, Goellner JR, Zimmerman D. Insular thyroid carcinoma in adolescents: a potentially lethal endocrine malignancy. Cancer. 1997;79(5):1044-8. http://dx.doi.org/10.1002/(SICI)1097-0142(19970301)79:5<1044::AIDCNCR23>3.0.CO;2-0. PMid:9041169.

26. Patel A, Jhiang S, Dogra S, Terrell R, Powers PA, Fenton C, Dinauer CA, Tuttle RM, Francis GL. Differentiated thyroid carcinoma that express sodium-iodide symporter have a lower risk of recurrence for children and adolescents. Pediatr Res. 2002;52(5):737-44. http://dx.doi.org/10.1203/00006450-200211000-00021. PMid:12409522.

27. Faggiano A, Coulot J, Bellon N, Talbot M, Caillou B, Ricard M, Bidart JM, Schlumberger M. Age dependent variation of follicular size and expression of iodine transporters in human thyroid tissue. J Nucl Med. 2004;45(2):232-7. PMid:14960641.

28. Castro MR, Bergert ER, Goellner JR, Hay ID, Morris JC. Immunohistochemical analysis of sodium iodide symporter expression in metastatic differentiated thyroid cancer: correlation with radioiodine uptake. J Clin Endocrinol Metab. 2001;86(11):5627-32. http://dx.doi.org/10.1210/jcem.86.11.8048. PMid:11701745.

29. Min JJ, Chung JK, Lee Y, Jeong JM, Lee DS, Jang JJ, Lee MC, Cho BY. Relationship between expression of the sodium/iodide symporter and 131। uptake in recurrent lesions of differentiated thyroid carcinoma. Eur J Nucl Med. 2001;28(5):639-45. http://dx.doi.org/10.1007/s002590100509. PMid:11383871.

30. Mazzaferri EL, Massoll N. Management of papillary and follicular (differentiated) thyroid cancer: new paradigms using recombinant human thyrotropin. Endocr Relat Cancer. 2002;9(4):227-47. http://dx.doi.org/10.1677/erc.0.0090227. PMid:12542401.

31. Mazzaferri EL, Kloos RT. Clinical review 128: current approaches to primary therapy for papillary and follicular thyroid cancer. J Clin Endocrinol Metab. 2001;86(4):1447-63. http://dx.doi.org/10.1210/jcem.86.4.7407. PMid:11297567.

32. Maia AL, Ward LS, Carvalho GA, Graf H, Maciel RM, Maciel LM, Rosário PW, Vaisman M. Nódulos de tireoide e câncer diferenciado de tireoide: consenso Brasileiro. Arq Bras Endocrinol Metabol. 2007;51(5):867-93. http://dx.doi.org/10.1590/ S0004-27302007000500027. PMid:17891253. 


\section{*Correspondence}

João Henrique Cunha Villela

Hospital Infantil Joana de Gusmão

Rua Rui Barbosa, 152, Agronômica,

Gabinete da Direção

CEP 88025-301, Florianópolis (SC),

Brasil

Telefone: +55 (48) 3251-9000

E-mail: jhcvillela@yahoo.com.br

\section{Authors information}

JHCV, CMM, FC, VMB - Residents, Head and Neck Surgery Programm, Centro de Pesquisas Oncológicas (CEPON). LRMS - Full Professor, Head and Neck Surgery Department, Hospital Infantil Joana de Gusmão.
33. Cooper DS, Doherty GM, Haugen BR, Kloos RT, Lee SL, Mandel SJ, Mazzaferri EL, Mclver B, Pacini F, Schlumberger M, Sherman SI, Steward DL, Tuttle RM, American Thyroid Association (ATA) Guidelines Taskforce on Thyroid Nodules and Differentiated Thyroid Cancer. Revised American thyroid association management guidelines for patients with thyroid nodules and differentiated thyroid cancer. Thyroid. 2009;19(11):1167-214. http://dx.doi.org/10.1089/thy.2009.0110. PMid:19860577.

34. van Santen HM, Aronson DC, Vulsma T, Tummers RF, Geenen MM, de Vijlder $J$ J, van den Bos C. Frequent adverse events after treatment for childhood onset differentiated thyroid carcinoma: a single institute experience. Eur J Cancer. 2004;40(11):1743-51. http://dx.doi.org/10.1016/j.ejca.2004.03.006. PMid:15251165.

35. Pacini F, Schlumberger M, Dralle H, Elisei R, Smit JW, Wiersinga W, European Thyroid Cancer Taskforce. European consensus for the management of patients with differentiated thyroid carcinoma of the follicular epithelium. Eur J Endocrinol. 2006;154(6):787-803. http://dx.doi.org/10.1530/eje.1.02158. PMid:16728537.

36. Verburg FA, de Keizer B, Lips CJ, Zelissen PM, Klerk JM. Prognostic significance of good response to initial therapy with radioiodine of differentiated thyroid cancer patients. Eur J Endocrinol. 2005;152(1):33-7. http://dx.doi.org/10.1530/ eje.1.01819. PMid:15762184.

37. Visman F, Bulzico DA, Pessoa CHCN, Bordallo MAN, Mendonca UBT, Dias FL, Coeli CM, Corbol R, Vaisman M. Prognostic factors of a good response to initial therapy in children and adolescents with differentiated thyroid cancer. Clinics. 2011;66(2):1-6. http://dx.doi.org/10.1590/S1807-59322011000200017.

38. Matuszewska G, Roskosz J, Włoch J, Jurecka-Tuleja B, Hasse-Lazar K, Kowalczyk $P$, Jarzab B. Evaluation of effects of L-thyroxine therapy in differentiated thyroid carcinoma on the cardiovascular system-prospective study. Wiadomosci Lekarskie. 2001;54(Suppl 1):373-7. PMid:12182052.

39. Mazzaferri EL, Massoll N. Management of papillary and follicular (differentiated) thyroid cancer: new paradigms using recombinant human thyrotropin. Endocr Relat Cancer. 2002;9(4):227-47. http://dx.doi.org/10.1677/erc.0.0090227. PMid:12542401.

40. Silva KAS, Coelho RC, Agostini AP, Pereira LAF, Dall'Agnol, MM, Dal Lago L. Câncer de tireoide na infância e na adolescência: estudo de casos e revisão da literatura. Revista da AMRIGS. 2010;54(2):169-73. 